\title{
Analysis of Stroke Patients Requiring Re-hospitalisation for Rehabilitation
}

\author{
Rehabilitasyon için Tekrar Hastaneye Yatış Gereken Inme Hastalarının Analizi \\ (1) Tuğba Aydın, (1) Fatma Nur Kesiktaş, (D) Mustafa Çorum \\ istanbul Physical Medicine and Rehabilitation Training and Research Hospital, Clinic of Physical Medicine and Rehabilitation, Istanbul, Turkey
}

Abstract

Aim: The aim of this study is to investigate the pure rate of rehospitalisation in stroke patients hospitalised for rehabilitation purpose only.

Methods: Patients hospitalised according to International Statistical Classification of Diseases and Related Health Problems 10 (ICD 10) code with the following conditions are included in the study: flaccid hemiplegia (G81.0), spastic hemiplegia (G81.1), hemiplegia unspecified (G81.9). The study is conducted with two groups: patients hospitalised once $(n=290)$ and patients rehospitalised for stroke rehabilitation purposes $(n=38)$.

Results: The mean stroke duration is $12.3 \pm 23.5$ months. The rate of rehospitalisation is $11.6 \%$. The mean length of hospital stay is $41.4 \pm 22.1$ days in the hospitalised once group and $40.0 \pm 20.1$ days in the rehospitalisation group. There are no significant differences between the re-hospitalised and hospitalised once groups in stroke duration, length of hospital stay, Brunnstrom recovery stages for the upper and lower extremities, functional ambulation score and vitamin B12 and D levels.

Conclusion: The pure rehospitalisation rate is unknown due to the many different comorbid diseases included in the rehospitalisation rate for stroke patients. Our study provides the rate of rehospitalisation for rehabilitation purposes only. Indeed, the rehospitalisation rate is low in stroke patients hospitalised for rehabilitation purposes only.

Keywords: Stroke, hospitalization, rehabilitation

\section{Öz}

Amaç: Bu çalışmanın amacı, sadece rehabilitasyon amacıyla hastaneye yatırılan inmeli hastaların yeniden hastaneye yatış oranlarını araştırmaktı.

Yöntemler: Hastalıkların ve İlgili Sağlık Sorunlarının Uluslararası İstatistiksel Sınıflaması 10 (ICD 10) koduna göre flaksid hemipleji (G81.0), spastik hemipleji (G81.1) ve hemipleji tanımlanmamış (G81.9) tanısı ile hastanemize yatırılan hastalar çalışmaya dahil edildi. Çalışmaya alınan hastalar iki gruba ayrıldı; birinci grup rehabilitasyon için sadece bir kez hastaneye yatırılan hastaları ( $n=290)$, diğer grup ise aynı hastalardan rehabilitasyon amacıyla yeniden hastaneye yatırılan hastaları $(n=38)$ içermekteydi.

Bulgular: Hastaların inmeden sonra geçen süresi ortalama $12,3 \pm 23,5$ aydı. Yeniden yatış oranı \%11,6 idi. Hastanede kalış süresi sadece bir kez hastaneye yatırılan grupta $41,4 \pm 22,1$ gün, yeniden yatış grubunda ise $40,0 \pm 20,1$ gün idi. Ortalama inme süresi, hastanede yatış süresi, Brunnstrom'un üst ve alt ekstremite skoru, fonksiyonel ambülasyon skoru, B12 vitamini ve $D$ vitamini düzeyleri arasında anlamlı fark yoktu.

Sonuç: Literatürde inme hastalarında yeniden yatış oranları değerlendirilirken komorbid hastalıklar nedeni ile olan yatışlar da bu orana dahil edildiğinden sadece rehabilitasyon için gerçek yeniden yatış oranları bilinmemektedir. Yalnızca rehabilitasyon amacıyla hastaneye yatırılan inme hastalarında rehabilitasyon nedenli yeniden hastaneye yatış oranı daha düşük bulunmuştur.

Anahtar Sözcükler: Inme, hospitalizasyon, rehabilitasyon
Address for Correspondence/Yazışma Adresi: Tuğba Aydın, İstanbul Physical Medicine and Rehabilitation Training and Research Hospital, Clinic of Physical Medicine and Rehabilitation, İstanbul, Turkey

E-mail: drtugbaaydin@gmail.com ORCID: orcid.org/0000-0002-0298-1485

Received/Geliş Tarihi: 06 October 2020 Accepted/Kabul Tarihi: 07 October 2020
${ }^{\circ}$ Copyright 2020 by The Medical Bulletin of istanbul Haseki Training and Research Hospital The Medical Bulletin of Haseki published by Galenos Yayınevi. ${ }^{\circledR}$ Telif Hakkı 2020 İstanbul Haseki Eğitim ve Araștıma Hastanesi Haseki Tıp Bülteni, Galenos Yayınevi tarafından yayınlanmıştır. 


\section{Introduction}

Each year, approximately fifteen million people suffer stroke worldwide. Of these, approximately five million die and another five million require rehabilitation due to morbidity and disability. Considering the social and economic burden associated with stroke, the aim of rehabilitation should be decreasing disability and it should, moreover, be cost-effective (1).

Length of hospital stay for post-stroke rehabilitation varies from country to country, and it is affected by various factors, such as stroke severity, patient age, patient functional capacity, comorbid disease, rehabilitation success and healthcare funding. The average reported rehabilitation length of hospital stay is 17 days in the United States, 35 days in Canada and 75 days in England. Indeed, the length of hospital stay for stroke rehabilitation is generally quite long and expensive compared with other non-stroke diseases (2).

The rehospitalisation rate in patients who have experienced stroke varies from $20 \%$ to $27 \%$ in epidemiological studies (3). The cause of re-hospitalisation for patients suffering stroke is related to a number of other factors, such as respiratory tract infections and electrolyte disorders (3). Overall, $13 \%$ of all treatment costs are due to rehospitalisation in stroke patients (4), and the leading cause of re-hospitalisation is early discharge from hospital $(2,5)$. In the existing literature, the rehospitalisation rate includes stroke-rehabilitation purposes as well as other comorbid diseases. Accordingly, the aim of this study is to investigate stroke patients re-hospitalised for stroke rehabilitation only.

\section{Methods}

Ethical approval of the Ethics Committee of the Bakırköy Dr. Sadi Konuk Training and Research Hospital (number: 2018-449) was granted. This was a retrospective descriptive study. The unique protocol IDs were IstPMRTRH-449 and NCT03927469, which were obtained from ClinicalTrials. gov. According to International Statistical Classification of Diseases and Related Health Problems 10 (ICD 10) code, the patients included in the study were hospitalised between January 2015 and January 2019 due to hemiplegia (G81), flaccid hemiplegia (G81.0), spastic hemiplegia (G81.1) and hemiplegia unspecified (G81.9). The patients were selected by scanning the hospital database.

Overall, three hundred eight stroke patients who had no traumatic injury, no intracranial cancer and no intracranial surgery were included in the study. The first group, called the 'no rehospitalisation group', included patients who were hospitalised only once. The second group, called the 'rehospitalisation group', included 38 patients who were re-hospitalised for stroke rehabilitation only. The following factors were evaluated: age, sex, hemiplegia aetiology, season of admission, hemiplegia duration, 25(OH) vitamin D levels, vitamin B12 levels, Brunnstrom recovery stages (upper extremity, lower extremity and hand) and Functional Ambulation Classification (FAC).

In particular, Brunnstrom's staging was used to evaluate the motor development of stroke patients in six stages. The flask phase without the any voluntary movement was stage 1, whereas the presence of isolated movements was stage six (6). FAC is defined in five stages according to the basic motor skills required for functional ambulation. FAC stage 0 is used to indicate non-functional ambulation and stage 5 is used to indicate independent walking at each speed and on ground (7).

\section{Statistical Analysis}

The mean, standard deviation, median, range, frequency and ratio values were used in the descriptive statistics of the data. The Kolmogorov-Smirnov test was used to evaluate the distribution of the variables. The Mann-Whitney $U$ test was used to analyse the quantitative independent data, and the chi-square test was used in the analysis of qualitative independent data. In addition, the Wilcoxon test was used in the analysis of quantitative dependent data. Spearman's correlation coefficient was used to identify correlative relationships. The Statistical Package for the Social Sciences version 22.0 software was also used in the analysis.

\section{Results}

Statistical analysis was conducted with a total of 328 patients. The mean age of the patients was $65.2 \pm 12.9$ years. Of these patients, $35.1 \%(n=115)$ were female and $64.9 \%(n=213)$ were male. The mean stroke duration was $12.3 \pm 23.5$ months. Overall, $17.1 \%(n=56)$ of the patients had haemorrhagic stroke and $82.9 \%(n=272)$ had ischaemic stroke. The no re-hospitalisation group included 290 (88.4\%). The re-hospitalisation group included 38 patients $(11.6 \%)$. The mean of $25(\mathrm{OH})$ vitamin D level was $16.8 \pm 14.1 \mathrm{ng} / \mathrm{mL}$ and the mean of vitamin B12 level was $398.1 \pm 276 \mathrm{pg} / \mathrm{mL}$ (Table 1).

Age, sex, stroke duration, seasonal distribution and stroke aetiology were statistically similar between the no rehospitalisation group and the rehospitalisation group ( $p>0.05$ ). The mean length of hospital-stay was $41.4 \pm 22.1$ days in the no rehospitalisation group and $40.0 \pm 20.1$ days in the rehospitalisation group (Table 2).

Brunnstrom upper extremity scores, lower extremity scores and hand scores increased significantly in both groups upon discharge $(p<0.05)$. Indeed, there were no significant differences in Brunnstrom upper and lower extremity scores between the groups at admission and discharge $(p>0.05)$. In addition, there were no significant 
differences between the groups for Brunnstrom hand scores during admission ( $p>0.05$ ). However, Brunnstrom hand scores at discharge were significantly lower in the rehospitalisation group compared with the no rehospitalisation group $(p<0.05)$ (Table 2 ).

There was no significant difference in FAC scores at admission and discharge between the groups ( $p>0.05$ ). FAC scores increased significantly in both groups upon discharge compared with admission scores $(p<0.05)$ (Table 2). There was no significant difference in vitamin B12 and vitamin $D$ levels between the groups ( $p>0.05$ ) (Table 2 ).

There was no significant correlation between stroke duration and $25(\mathrm{OH})$ vitamin $D$ levels, lower extremity Brunnstrom scores and FAC scores ( $p>0.05)$. A significant negative correlation was observed between the duration of hemiplegia and vitamin B12 levels $(p<0.05)$. There was a significant positive correlation between stroke duration and Brunnstrom upper extremity scores and hand scores $(p<0.05)$. A significant positive correlation was observed between vitamin B 12 and $25(\mathrm{OH})$ vitamin D levels $(p<0.05)$. There was no significant correlation between 25(OH) vitamin D and FAC and Brunnstrom hand, upper and lower extremity scores $(p>0.05)$ (Table 3 ).

\section{Discussion}

The length of hospital-stay is longer, more expensive and mortality rate is higher in stroke patients than in those with other medical diagnoses. In addition, stroke patients have higher rehospitalisation rate than patients with other diseases (8). Unfortunately, relatively few studies exist about rehospitalisation rates in stroke patients $(9,10)$, and the studies that do exist are not restricted to stroke, but, rather, include other comorbid diseases, such as diabetes and pneumonia. In other words, the number of studies investigating the rates of re-hospitalisation for strictly rehabilitation purposes is limited. Accordingly, we designed this study to understand the factors related to rehospitalisation for rehabilitation only.

In the literature, the incidence of stroke is higher in men than in women, which is consistent with our study since $64.9 \%$ of patients were male. In our study, ischaemic strokes accounted for $82 \%$ of cases (32\% large vessel occlusion/infarction, $32 \%$ embolism and $18 \%$ small vessel occlusion) and haemorrhagic strokes accounted for $18 \%$ (11\% intracerebral haemorrhage and $7 \%$ subarachnoid haemorrhage) $(11,12)$. Indeed, the ischaemic/haemorrhagic rates are similar to those in the literature.

In the literature, the rate of rehospitalisation of stroke patients varies depending on age, time since discharge, stroke severity and impairment type. In a study by Johansen et al. (13), stroke patients were examined over a year. Here in, re-hospitalisation rates including all comorbid diseases were found to be between 25\% and 37\% (13). In a study by Tseng and Lin (14), $49.5 \%$ of stroke patients were re-hospitalised within one year for stroke and other comorbid diseases. The rate of rehospitalisation in our study was relatively low at $11.6 \%$, which can be attributed to the acceptance of patients who were eligible for only rehabilitation. In other words, patients with other life-threatening diseases, such as acute stroke, cardiac problems, electrolyte disorders and pneumonia, were not accepted for rehabilitation in our study.

Ottenbacher et al. (3) examined 80-180 days' worth of data of 15,992 stroke patients after discharge, finding no relationship between gender and age with regard to the rehospitalisation rate. We did not find any study that compared stroke duration with re-hospitalisation rates in the literature search. In our study, contrary to expectations,

\begin{tabular}{|c|c|c|c|c|c|}
\hline & & \multicolumn{2}{|l|}{ Min-max } & Median & Mean \pm SD $(n, \%)$ \\
\hline \multicolumn{2}{|l|}{ Age } & \multicolumn{2}{|l|}{$16.0-90.0$} & 65.0 & $65.2 \pm 12.9$ \\
\hline \multirow{2}{*}{ Sex } & Female & & - & - & $115 \pm 35.1$ \\
\hline & Male & & & & $213 \pm 64.9$ \\
\hline \multirow{2}{*}{ Side } & Right & & - & - & $152 \pm 46.3$ \\
\hline & Left & & & & $176 \pm 53.7$ \\
\hline \multicolumn{2}{|c|}{ Stroke duration (month) } & \multicolumn{2}{|l|}{$1.0-165.0$} & 3.0 & $12.3 \pm 23.5$ \\
\hline \multirow{2}{*}{ Etiology } & Haemorrhagic & & - & - & $56 \pm 17.1 \%$ \\
\hline & Ischemic & & & & $272 \pm 82.9 \%$ \\
\hline \multirow{2}{*}{ Re-hospitalization } & $(-)$ & & - & - & $290 \pm 88.4 \%$ \\
\hline & $(+)$ & & & & $38 \pm 11.6 \%$ \\
\hline \multicolumn{2}{|c|}{$25(\mathrm{OH})$ vitamin $\mathrm{D}(\mathrm{ng} / \mathrm{mL})$} & \multicolumn{2}{|l|}{$3.0-70.0$} & 13.0 & $16.8 \pm 14.1$ \\
\hline \multicolumn{2}{|c|}{ Vitamin B12 $(\mathrm{pg} / \mathrm{mL})$} & \multicolumn{2}{|l|}{$7.0-2000.0$} & 322.0 & $398.1 \pm 276.0$ \\
\hline
\end{tabular}




\section{Table 2. Comparison of the no re-hospitalization and re-hospitalization groups}

\begin{tabular}{|c|c|c|c|c|c|c|c|}
\hline \multirow{3}{*}{\multicolumn{2}{|c|}{\begin{tabular}{|l|} 
\\
Age
\end{tabular}}} & \multicolumn{2}{|c|}{ No re-hospitalization group } & \multicolumn{2}{|c|}{ Re-hospitalization group } & \multirow{2}{*}{\multicolumn{2}{|c|}{ p }} \\
\hline & & \multirow{3}{*}{$\begin{array}{l}\text { Mean } \pm \text { SD (n, \%) } \\
65.2 \pm 13.1 \\
102 \pm 35.2 \%\end{array}$} & \multirow{2}{*}{$\begin{array}{l}\text { Median } \\
65.0\end{array}$} & \multirow{2}{*}{$\begin{array}{l}\text { Mean } \pm \text { SD (n, \%) } \\
65.5 \pm 11.3\end{array}$} & \multirow{2}{*}{$\begin{array}{l}\text { Median } \\
65.0\end{array}$} & & \\
\hline & & & & & & 0.951 & $\mathrm{~m}$ \\
\hline \multirow{2}{*}{ Sex } & Female & & & $13 \pm 34.2 \%$ & & \multirow{2}{*}{0.907} & \multirow{2}{*}{$\chi^{2}$} \\
\hline & Male & $188 \pm 64.8 \%$ & & $25 \pm 65.8 \%$ & & & \\
\hline \multicolumn{2}{|c|}{ Stroke duration (month) } & $10.9 \pm 20.6$ & 3.0 & $20.6 \pm 36.0$ & 7.5 & 0.068 & m \\
\hline \multicolumn{2}{|c|}{ Duration of initial hospital stay (days) } & $41.4 \pm 22.1$ & 42.0 & $40.0 \pm 20.1$ & 40.0 & 0.823 & m \\
\hline \multirow{4}{*}{ Season } & Spring & $62 \pm 21.4 \%$ & & $8 \pm 21.1 \%$ & & \multirow{4}{*}{0.799} & \multirow{4}{*}{$x^{2}$} \\
\hline & Summer & $68 \pm 23.4 \%$ & & $7 \pm 18.4 \%$ & & & \\
\hline & Autumn & $60 \pm 20.7 \%$ & & $7 \pm 18.4 \%$ & & & \\
\hline & Winter & $100 \pm 34.5 \%$ & & $16 \pm 42.1 \%$ & & & \\
\hline \multirow{2}{*}{ Etiology } & Haemorrhagic & $52 \pm 17.9 \%$ & & $4 \pm 10.5 \%$ & & \multirow{2}{*}{0.254} & \multirow{2}{*}{$\chi^{2}$} \\
\hline & Ischemic & $238 \pm 82.1 \%$ & & $34 \pm 89.5 \%$ & & & \\
\hline \multicolumn{8}{|c|}{ Brunnstrom's upper extremity } \\
\hline \multicolumn{2}{|c|}{ Admission score } & $2.8 \pm 1.9$ & 2.0 & $2.2 \pm 1.4$ & 2.0 & 0.068 & $\mathrm{~m}$ \\
\hline \multicolumn{2}{|c|}{ Discharge score } & $3.4 \pm 1.7$ & 3.0 & $2.8 \pm 1.5$ & 2.0 & 0.125 & m \\
\hline \multicolumn{2}{|l|}{$p$} & \multicolumn{2}{|l|}{0.000 w } & \multicolumn{4}{|l|}{$0.000 w$} \\
\hline \multicolumn{8}{|c|}{ Brunnstrom's hand } \\
\hline \multicolumn{2}{|c|}{ Admission score } & $2.8 \pm 2.0$ & 2.0 & $2.1 \pm 1.5$ & 1.0 & 0.062 & m \\
\hline \multicolumn{2}{|c|}{ Discharge score } & $3.4 \pm 1.7$ & 3.0 & $2.7 \pm 1.5$ & 2.0 & 0.041 & m \\
\hline \multicolumn{2}{|l|}{$p$} & \multicolumn{2}{|l|}{0.000 w } & $0.000^{w}$ & & & \\
\hline Brunnstrc & ver extremity & & & & & & \\
\hline Admission & & $3.1 \pm 1.7$ & 3.0 & $2.9 \pm 1.6$ & 3.0 & 0.671 & m \\
\hline Discharge & & $3.8 \pm 1.5$ & 4.0 & $3.6 \pm 1.5$ & 3.0 & 0.426 & $\mathrm{~m}$ \\
\hline$p$ & & $0.000^{w}$ & & $0.000^{w}$ & & & \\
\hline FAC & & & & & & & \\
\hline Admission & & $1.4 \pm 1.3$ & 1.0 & $1.2 \pm 1.2$ & 1.0 & 0.614 & $\mathrm{~m}$ \\
\hline Discharge & & $2.5 \pm 1.6$ & 2.0 & $1.9 \pm 1.2$ & 2.0 & 0.084 & $\mathrm{~m}$ \\
\hline$p$ & & $0.000^{w}$ & & $0.000^{w}$ & & & \\
\hline $25(\mathrm{OH})$ vit & $\mathrm{ng} / \mathrm{mL})$ & $16.9 \pm 14.3$ & 13.0 & $15.9 \pm 13.4$ & 10.0 & 0.622 & $\mathrm{~m}$ \\
\hline Vitamin B & & $398.3 \pm 284.8$ & 320.0 & $396.9 \pm 216.8$ & 325.0 & 0.619 & $\mathrm{~m}$ \\
\hline
\end{tabular}

Table 3. Correlation of data, admission scores, and levels

\begin{tabular}{|c|c|c|c|c|c|c|c|c|}
\hline & & $\begin{array}{l}\text { Stroke duration } \\
\text { (months) }\end{array}$ & Vitamin B12 & Vitamin D & $\begin{array}{l}\text { Brunnstrom's } \\
\text { upper extremity }\end{array}$ & $\begin{array}{l}\text { Brunnstrom's } \\
\text { hand }\end{array}$ & $\begin{array}{l}\text { Brunnstrom's } \\
\text { lower extremity }\end{array}$ & FAC \\
\hline \multirow{2}{*}{$\begin{array}{l}\text { Stroke duration } \\
\text { (months) }\end{array}$} & $r$ & - & -0.174 & 0.018 & 0.153 & 0.159 & -0.002 & 0.101 \\
\hline & $p$ & - & 0.022 & 0.807 & 0.034 & 0.028 & 0.980 & 0.207 \\
\hline \multirow{2}{*}{ Vitamin B12 } & $r$ & - & & 0.163 & -0.039 & -0.187 & -0.113 & -0.082 \\
\hline & $p$ & - & & 0.029 & 0.609 & 0.613 & 0.135 & 0.320 \\
\hline \multirow{2}{*}{$25(\mathrm{OH})$ vitamin $D$} & $r$ & - & & & -0.084 & -0.081 & -0.118 & -0.068 \\
\hline & $p$ & & & & 0.256 & 0.273 & 0.111 & 0.395 \\
\hline
\end{tabular}


stroke duration was not statistically significant for the no rehospitalisation group and re-hospitalisation group.

Ottenbacher et al. (3) considered the most important factor in the rehospitalisation of patients to be a short initial hospital stay ( $25.3 \pm 14.7$ days). In contrast to Ottenbacher et al.'s study (3), the length of initial hospital-stay for our patients was long in the re-hospitalisation group (40.0 \pm 20.1 days). In addition, no significant differences were identified between the no rehospitalisation group and the re-hospitalisation group, suggesting that a long initial hospital stay upon admission does not positively affect the rehospitalisation rate.

In another study by Ottenbacher et al. (15), stroke patients were examined for rehospitalisation rate for three months, finding that stroke aetiology (haemorrhagic and ischaemic) is not a significant variable in the rehospitalisation rate, which is consistent with the findings of our study.

In our study, the upper-extremity motor levels, lowerextremity motor levels and ambulation levels increased significantly in both groups after rehabilitation. However, hand-motor healing was lower in the rehospitalisation group compared with the no re-hospitalisation group. In addition, hand recovery was lower in patients with hand paralysis and no measurable grasp strength in the fourth week (12). Although there was no statistically significant difference in the stroke duration, long hemiplegia duration resulted in less hand healing in the re-hospitalisation group. In our study, the mean duration of hemiplegia was 20 months in the re-hospitalisation group. Indeed, it was important to be careful when planning hand rehabilitation during admission for the re-hospitalisation group, because hand-rehabilitation healing was minimal in our study.

The low functional status of patients has been shown to be the most important factor in increased rehospitalisation rates with respect to studies investigating rehospitalisation causes $(15,16)$. Functional ambulation status was investigated using the Functional Ambulation Categories (FAC) scale in our study. Indeed, the functional ambulation levels of the patients were not statistically significant between the two groups; however, there was a significant improvement after rehabilitation when compared with the initial scores.

In studies investigating low $25(\mathrm{OH})$ vitamin D levels in stroke patients, low levels were associated with an increased risk of hip fracture, cardiovascular disease and sarcopenia (among others) $(17,18)$. In our study, the average value of the $25(\mathrm{OH})$ vitamin D levels was 16.8 $\mathrm{ng} / \mathrm{mL}$, constituting a deficiency level for both groups. Indeed, the majority of researchers agree that a $25(\mathrm{OH})$ vitamin D level above $30 \mathrm{ng} / \mathrm{mL}$ (75 nmol/L) is sufficient, between 20 and $30 \mathrm{ng} / \mathrm{mL}(50-75 \mathrm{nmol} / \mathrm{L})$ is insufficient, and below $20 \mathrm{ng} / \mathrm{mL}(50 \mathrm{nmol} / \mathrm{L})$ is deficient $(19,20)$. We found no significant differences in the $25(\mathrm{OH})$ vitamin $\mathrm{D}$ levels between the no re-hospitalisation and rehospitalisation groups. Moreover, levels of $25(\mathrm{OH})$ vitamin $D$ were not associated with the season of hospitalisation, which can be explained by low ambulation scores (mean FAC score was 1 in the no rehospitalisation group), indicating that the patients were dependent on other people for mobility and, therefore, mostly resided in nonsolar closed areas.

In the literature, high serum vitamin B12 levels in hemiplegia patients have been associated with optimal functional outcomes (16). Indeed, many studies have reported that vitamin B12 deficiency increases the risk of stroke $(17,18)$. Generally, vitamin B12 levels higher than $400 \mathrm{pg} / \mathrm{mL}$ are classified as sufficient, between $150-399 \mathrm{pg} / \mathrm{mL}$ as insufficient and below $150 \mathrm{pg} / \mathrm{mL}$ as deficient (21). The mean vitamin B12 level in our patients was $398.1 \mathrm{pg} / \mathrm{mL}$. Moreover, we found no significant difference between the no rehospitalisation group and the rehospitalisation group.

Although 25(OH) vitamin D level was found to be low in our study, this situation was not associated with stroke duration. Indeed, 40\% of stroke patients experienced dysphagia and $16 \%$ experienced malnutrition $(22,23)$. This information explains the negative correlation between vitamin B12 levels and stroke duration, which can be attributed to malnutrition.

In our study, the Brunnstrom upper extremity and hand scores had positive correlations with stroke duration. This situation can be explained by motor-level rehabilitation, which is worse in the acute period after stroke (12).

\section{Study Limitations}

Many comorbid diseases were included in the rehospitalisation rates in stroke patients in the literature. The real rates of rehospitalisation are not well-known in patients admitted for rehabilitation purposes only. Unlike the literature, our study provides pure re-hospitalisation rates for rehabilitation purposes only.

\section{Conclusion}

In the literature, pure re-hospitalisation rates are unknown. Accordingly, in this study, pure rehospitalisation rates for rehabilitation purposes only are examined. Indeed, the re-hospitalisation rate was low in stroke patients who were hospitalised for rehabilitation purposes only. Moreover, re-hospitalisation rates were not associated with length of initial hospital-stay, stroke duration and FAC. 


\section{Authorship Contributions}

Concept: F.N.K., Design: F.N.K., T.A., Data Collection or Processing: T.A., Analysis or Interpretation: F.N.K., T.A, M.Ç., Literature Search: T.A., M.Ç., Writing: T.A.

Conflict of Interest: This study was conducted as a master's thesis. The authors confirm that this article's content has no conflicts of interest.

Financial Disclosure: The authors declared that this study received no financial support.

\section{References}

1. Lo K, Stephenson M, Lockwood C. The economic cost of robotic rehabilitation for adult stroke patients: a systematic review. JBI Database System Rev Implement Rep 2019;17:52047.

2. Grant C, Goldsmith $\mathrm{CH}$, Anton HA. Inpatient stroke rehabilitation lengths of stay in Canada derived from the National Rehabilitation Reporting System, 2008 and 2009. Arch Phys Med Rehabil 2014;95:74-8.

3. Ottenbacher KJ, Smith PM, Illig SB, Fiedler RC, Gonzales V, Granger CV. Characteristics of persons rehospitalized after stroke rehabilitation. Arch Phys Med Rehabil 2001;82:136774.

4. Osberg JS, McGinnis GE, Dejong G, Seward ML, Germaine J. Long-term utilization and charges among post-rehabilitation stroke patients. Am J Phys Med Rehabil 1988;67:66-72.

5. Lohr KN, Schroeder SA. A strategy for quality assurance in Medicare. N Engl J Med 1990;322:707-12.

6. Brunnstrom S. Motor testing procedures in hemiplegia: based on sequential recovery stages. Phys Ther 1966;46:357-75.

7. Holden MK, Gill KM, Magliozzi MR, Nathan J, Piehl-Baker L. Clinical gait assessment in the neurologically impaired: reliability and meaningfulness. Phys Ther 1984;64:35-40.

8. Dossa A, Glickman ME, Berlowitz D. Association between mental health conditions and rehospitalization, mortality, and functional outcomes in patients with stroke following inpatient rehabilitation. BMC Health Serv Res 2011;11:311.

9. Lakshminarayan K, Schissel C, Anderson DC, et al. Fiveyear rehospitalization outcomes in a cohort of patients with acute ischemic stroke: Medicare linkage study. Stroke 2011;42:1556-62.

10. Sun $Y$, Lee $\mathrm{SH}$, Heng BH, Chin VS. 5-year survival and rehospitalization due to stroke recurrence among patients with hemorrhagic or ischemic strokes in Singapore. BMC Neurol 2013;13:133.

11. Turtzo LC, McCullough LD. Sex differences in stroke. Cerebrovasc Dis 2008;26:462-74.

12. Nelson ML, McKellar KA, Yi J, et al. Stroke rehabilitation evidence and comorbidity: a systematic scoping review of randomized controlled trials. Top Stroke Rehabil 2017;24:37480.

13. Johansen HL, Wielgosz AT, Nguyen K, Fry RN. Incidence, comorbidity, case fatality and readmission of hospitalized stroke patients in Canada. Can J Cardiol 2006;22:65-71.

14. Tseng MC, Lin HJ. Readmission after hospitalization for stroke in Taiwan: results from a national sample. J Neurol Sci 2009;284:52-5.

15. Ottenbacher K, Graham J, Ottenbacher A, et al. Hospital readmission in persons with stroke following postacute inpatient rehabilitation. J Gerontol A Biol Sci Med Sci 2012;67:875-81.

16. Roberts PS, DiVita MA, Riggs RV, Niewczyk P, Bergquist B, Granger CV. Risk factors for discharge to an acute care hospital from inpatient rehabilitation among stroke patients. PM\&R 2014;6:50-5.

17. Sato $Y$, Asoh T, Kondo I, Satoh K. Vitamin D deficiency and risk of hip fractures among disabled elderly stroke patients. Am Heart Assoc 2001;32:1673-7.

18. Sato Y, Iwamoto J, Kanoko T, Satoh K. Low-dose vitamin D prevents muscular atrophy and reduces falls and hip fractures in women after stroke: a randomized controlled trial. Cerebrovasc Dis 2005;20:187-92.

19. Artese HPC, Foz AM, de Sousa Rabelo M, et al. Periodontal therapy and systemic inflammation in type 2 diabetes mellitus: a meta-analysis. PLoS One 2015;10:e0128344.

20. Holick MF. Vitamin D deficiency. N Engl J Med 2007;357:26681.

21. Langan RC, Goodbred AJ. Vitamin B12 deficiency: recognition and management. Am Fam Physician 2017;96:384-9.

22. Sabbouh T, Torbey MT. Malnutrition in stroke patients: risk factors, assessment, and management. Neurocrit Care 2018;29:374-84.

23. Cohen DL, Roffe C, Beavan J, et al. Post-stroke dysphagia: a review and design considerations for future trials. Int I Stroke 2016;11:399-411. 